\title{
Reading Habits and Their Influence on Academic Achievement Among Students at Asia Pacific International University
}

\author{
Sasikala Balan ${ }^{1}$, Josephine Esther Katenga ${ }^{2}$, Amanda Simon ${ }^{3}$ \\ Faculty of Education Asia-Pacific International University, Thailand \\ philipjasmine@gmail.com
}

\begin{abstract}
In this study reading habits have been correlated with academic achievement. Students who have developed the habits of reading academic and non-academic materials develop their comprehension of concepts, critical thinking skills, and verbal fluency and ultimately have better academic outcomes. This quantitative study examined reading habits and their influence on the academic achievements of students at Asia-Pacific International University, Mauk Lek, Thailand. A convenience sampling method was utilized to select 250 individuals who responded to a survey questionnaire, A Statistical Package for Social Science (SPSS) was used to analyze the data. A multiple regression and Correlation Matrix analysis checked the influence of reading habits on academic achievement. Among the five variables, the study confirmed that the purpose of reading has a significant relationship with academic performance. Furthermore, the findings indicated that the majority of the respondents value the importance of reading. However, the respondents had low reading habits. The study recommends that policymakers in universities should develop plans and for increasing students' reading habits. This includes providing resources to encourage students to take up reading. In addition, administrators should develop strategies for teachers to create activities that can promote reading habits, which would, in turn, improve students' academic performance.
\end{abstract}

Keywords: Reading. Reading habits, Academic achievement, Cumulative grade point average (CGPA)

\section{INTRODUCTION}

\section{Background of the Study}

Reading habits have been singled out to immensely affect the scholarly output of the students (Cunningham \& Stanovovich, 2001; Hangu, Capps, Blacklock, \& Garza, 2014; Levine, Waite \& Bowman, 2007). It is an indispensable method of acquiring knowledge and is essential for higher academic performance (Bashir \& Mattoo, 2012), and it determines the success of university students around the globe. Students who are interested in reading including non- 
academic literature, increase their emotional and academic intelligence (Okwilagwe, 1998). If students possess good reading habits, they can increase their critical reasoning skills and ultimately have better academic outcomes. In addition, even the reading of non-academic books enhances students' language skills.

However, Asagwara (2001) indicates that weak reading habits negatively affect students' comprehension, thus affecting their performance and advancement. Even capable students who reduce their reading underperform academically (Levine, Waite \& Bowman, 2007). Nevertheless, some students who have under-developed reading skills have shown marked progress after participating in extensive reading projects (Anderson. Wilson \& Fielding (1988). Unfortunately, leisure time preferences have become increasingly bent towards technology and social media instead of reading (Obaidullah \& Rahman, 2018). The use of, YouTube, Facebook and other online websites make it easier for students to watch videos and other online programs and they ignore reading (Obaidullah \& Rahman, 2018; Palani, 2012).; Palani, 2012). Consequently, an increasing number of students have a negative attitude towards academic reading. It is because of these reasons that the number of students who read outside the classroom has declined at an alarming rate.

Home environments and cross-cultural issues also affect reading habits (Ameyaw, Anto, 2017; Chen, Yang, 2014; Heath et al., 2014). Those who have read from the time they were young, excel in reading and are more knowledgeable (Cunningham \& Stanovich, 2001; Peaerson, 2013) while those who come from low-income families or cultures where reading is not introduced or emphasized, display very poor reading skills (Snow, Burns \& Griffin, 1998). In some Ghanaian village home environments where there is a lack of reading resources and where children are expected to do chores at home instead of reading, it is difficult for them to form reading habits ( Ameyaw \& Anto, 2018; Yamoah, 2015), and this impacts their college reading habits.

Some Southeast Asia countries, the governments are struggling to raise the reading level. Thailand is no different from schools in Southeast Asia. It has one of the worst reading records. Reading has not been emphasized beyond textbooks, even at the university level. However, the ASEA Libraries have taken up the battle to promote reading to children (Choomthong, 2014; Sangkaeo, 1999). In other countries like Indonesia, teacher's efforts to increase reading habits are paying off. However, the level of reading is still unsatisfactory (Poedjiastutie., 2018) These issues necessitates the investigation of reading habits and its effect on academic performance.

\section{Problem Statement and Purpose of the Study}


Literature shows that the distractions from technology and social media have caused the decline of reading habits among college students and has increased students' lack of passion for reading (Briggs, 1987; Palani, 2012). In addition, some students do not acquire reading habits because of their specific home environments that are affected by poverty, traditional beliefs, and practices. Students from these environments who have little experience in reading find it hard to excel in college (Ameyaw \& Anto, 2018; Yamoah, 2015). The QECD (2014) survey in Thailand showed that Thai students performed poorly on PISA. The test also revealed that students' reading ability affected their academic achievement. This research, therefore, aimed at examining the influence of reading habits on academic achievement among students at Asia Pacific International University, Thailand. This study also focused on investigating the relationship between reading habits and academic achievement. The following were the research questions:

1. What are the reading habits of students at Asia Pacific International University?

2. What is the level of students' academic achievement?

3. Is there a relationship between reading habits and academic achievement?

\section{LITERATURE REVIEW}

Bond Tinker, Wasso, and Wasson (1994) claim that reading is a process in which individuals can distinguish the symbols from the reading patterns. Therefore, the reader can understand what is read and later remember the passages that he enjoyed. However, Chettri \& Rout (2013) understood reading as an optional step taken by people to critique various topics discussed in a passage and indicated that in learning, reading is the medium that helps people to gain a deeper understanding of the world around them.

Okwilagwe's (1998) definition of reading includes meaningful interpretation of words, phrases, and sentences. He states that reading requires different types of critical thinking such as analyzing, creating, imagining, evaluating, and problem-solving. The process of reading should also include understanding, questioning, interpreting, predicting, defining, the words, and the writer's meaning of the passage. This definition suggests that reading develops cognitive skills (Collins, Brown, \& Newman 1998; Kidd \& Castano, 2013; Whitten, Labby, \& Sullivan, 2016.). This definition corresponds with the conceptual understanding of this study.

\section{Reading as a Habit}

The activity of reading is considered a habit when it is frequently carried out. In other words, reading is measured in terms of materials read and the period spent on reading (Wagner, 2002). 
According to Chettri and Rout (2013), reading habits are "the number of materials being read, the frequency of reading as well and the average time spent on reading" (p.13). Similarly, Wagner et al. (2002) describe reading habits as the volume and the extent to which materials learned, and the maximum number of hours spent reviewing and reflecting on the concepts. In an academic context, reading assists the reader to increase their knowledge and wisdom. It helps students to retain information and brings significant changes in a person's social, spiritual, and economic status. The positive outcomes of effective reading habits can be seen when a student's comprehension expands (Okwilagwe, 1998). Therefore, for this study, reading habits are defined as purposely planning and spending time to read for leisure and academic material until a person forms an appetite for reading.

\section{Academic Achievement}

Academic achievement measures how successful students are and refers to the attainment of ones' scholastic goals. Crow and Crow (1996), defined academic achievement in terms of skill acquisition: "Academic achievement is reflected by the extent to which a person has acquired the skill of knowledge through the training imparted to him." (p. 345). However, academic achievement is measured after students take assessments tests by ratings decided upon and applied by the school. Achievement levels are often measured through a Grade Point Average (GPA) of the students' score.

\section{Factors That Affect Academic Achievement}

Apart from reading habits, other variables affect academic success. These factors include, instructional strategies and quality of teaching (Blazar, 2015; Ganyaupfu, 2013), peer support (Smithikrai, et al., 2018), family background (Mushtaq and Khan, 2012) and class attendance, (Hocking, 2008).

Tynjälä, Välimaa and Sarja (1998) observed that student-centered learning environments are essential for producing better learning outcomes than the traditional teacher-centered instruction models. Smithikrai, et al. (2018) after studying 802 Thai undergraduate university students, discovered that students' peer support, satisfaction with the quality of teaching and most importantly, the purpose for obtaining an education played a role in students' eagerness and effort to perform well in their academic studies. A study by Mushtaq and Khan (2012) conducted at private colleges in Pakistan revealed essential factors that affect the students' academic performance, these included: family background (economic status, parents level of education and parental guidance) types of communication, family stress, and learning facilities. Class attendance is also critical to academic achievement (Hocking, 2008). Aden, Yahye, 
Dahir, 2013 studied the effects of 100 Somalian university student's attendance records and found a positive relationship between students' attendance and academic achievement.

Other factors affecting academic achievement include race and gender, (Bignold, 2003; Hansen, 2000)), social-economic status (Adams, 1996; Walters \& Soyibo,1998), students' selfregulation (Adunola, 2011). the students' level of intelligence (Naderi, et al., 2009) and classroom attendance (Aden, Yahye, \& Dahir, 2013). Muhdin (2016) also revealed more variables that influence academic outcomes, such as students' sleeping time, university entrance exam score, and the family financial situation.

\section{The Effect of Reading Habits on Academic Achievement}

Literature posits that academic achievement is based on the students' development of reading habits (Annamalai \& Muniandy, 2013). A study conducted by Horbec's (2012) showed a strong relationship between reading habits and academic achievement. The reading habits significantly assists the students in their learning process and enhances their academic outcomes (Fatiloro, Oyekoa, \& Hameed, 2017; Kidd \& Castano, 2013; Whitten, Labby, \& Sullivan, 2016). The importance of reading habits surpasses the use of object lessons, blackboards, maps, pictures, and, even reading digital texts. Lessons taught through reading, eventually, help students to fix those lessons into the memory (Singer \& Alexander, 2017).

It is a proven fact that recreational reading is a catalyst for developing grammar and vocabulary (Krashen 2004, 2009; Krashen \& Williams, 2012). Reading for pleasure has an influence on the development and understanding of concepts, verbal fluency, comprehension, eloquence, vivid thinking, and academic achievements, (Cunningham and Stanovich, 1998; Whitten, Labby, \& Sullivan, 2016). On the other hand, lack of reading habits results in very poor grades. A study of 227 preservice teachers who had completed three years of their bachelors' degree had poor reading comprehension because they did not like reading and did not appreciate assignments. Those who enjoyed reading had better scores (Benevides \& Peterson, 2010).

\section{Reading Habits in South East Asia}

The Southeast Asian countries have difficulties raising the reading habits of their students. These governments are trying to raise the reading level of their students by promoting libraries (Poedjiastutie, 2018). A study conducted in Tangerang City in Indonesia showed that few people were in the habit of reading. The study revealed that the family also played an important role in academic performance when they provided their children with an environment for reading (Andayani \& Maryam, 2018). On the other hand, 96.6\% of students in Malaysia participated in academic reading because they looked for information that would help them 
with project information. Even though student read other non-fiction books, they do so to work on assignments.

Thailand is no different from schools in southeast Asia. It has one of the worst rending records Thailand was a hub of literacy in the 1890s. Male children were taught to read at a level comparable to or above that of Europe children because of the Buddhist culture (Asia Correspondent, 2012). Unfortunately, Thailand has become a culture that deemphasizes reading but believes in learning from the teachers and course material (OECD, 2014) A study by OECD (2014) revealed that Thai people do not view reading as a required activity. The students had low reading ability which affected their academic achievement on the PISA test (OECD, 2014).

A survey conducted by Peter J. Foley's of the Southeastern Asian countries (Singapore, Malaysia, Thailand, and Japan) reported in the Asian Correspondent (2012) revealed that Thailand had the lowest reading rate. Participants in Thailand read five books a year; while the Japanese had the highest number amongst the Southeastern Asian countries. Their average was reading 50 books a year. Perhaps one of the reasons is the consumption of media. A report by the National Statistical Office (2008) showed that Thais read approximately 39 minutes a day. This report drove the government to establish on April 2 the Reading Day and organized campaigns that promoted reading. This included distributing books to children, selling reasonably priced books and censoring harmful books and media (Ngamwittayaphong, 2011).

\section{Factors That Influence Reading Habits}

Several factors influence reading habits. Research shows that reading habits are related to age, gender, marital status, educational background and occupation, and parents educational background (Tor-Akwer \& Chorun, 2014). A study of 410 college students in India conducted by Allahi and Khandai (2015) presented finding that showed female college students' reading habits resulted in better academic outcomes because their reading habits were higher than that of males.

In addition to demographics, advancement in technology has brought about an influx of information and widespread use of media. Gunasekara (2002) discovered that Srilankan students spent much of their time online surfing the internet and continuously chatting, watching media and, neglected to study. They only crammed for their final exam. Liu (2000), in another study, observed that the students' first preference was to watch programs on television during their free time instead of reading. An international survey (Books Aid International, 2003) revealed that the reading capacity of tertiary students in the United 
Kingdom has decreased because of YouTube and sharing online content. Approximately half of the students read, and that they only do so at the time of the final examination.

It has been established that students' attitude to reading promotes or hinders the development of reading habits. Briggs (1987) argues that children's negative attitude to reading reduces their motivation to read. In a study of college teachers' in training, conducted by Applepgate, et all. (2014), it was discovered that most of the students had little enthusiasm for reading. Only $48.9 \%$ of these students were interested in reading. In another study by Bulgurcuoglu (2016), female pre-service teachers had a positive attitude toward reading and had better academic results.

A lot of students are lazy and have no interest in reading academic literature (Owusu-Acheaw \& Larson, 2014). Some students have learned to read in their homes, but as they get older and get into other hobbies, their attitude changes and they stop reading. Students who stopped regular reading in elementary or secondary school become slow learners when they go to college (Akabuike, \& Asika, 2012).

The family background and home environment can also affect reading habits. Students who never learned to read at home because they lacked reading materials and or because of parents' level of education, have difficulties developing reading habits (Ameyaw \& Anto, 2018; Yamoah, 2015). A study of 395 college students majoring in education (Capps \& Huang, 2015) reported that their parents never read to them when they were young (Capps \& Huang, 2015), and this affected their reading ability. In some Ghanaian villages poverty dictates whether students are interested in reading. The lack of reading materials or the distractions in the home environment makes it difficult for students to concentrate on reading (Acheaw, 2004: Ameyaw \& Anto, 2018; Yamoah, 2015).

Language skills of international students can be the reason for poor reading habits. Alghail \& Mahfoodh (2016) observed that international college students had difficulties in reading academic papers. The students found "taking brief and relevant notes; using own words in notetaking; working out the meanings of difficult words, and identifying supporting ideas/examples" (p. 379) daunting. These authors reasoned that students had reading problems and low English language skills because of little experience with academic reading materials.

\section{The Development of Reading Habits}

Reading habits can be nurtured and cultivated (Bahruddin, Hasnol, Ramsi \& Kadir, 2015) through the proper guidance of parents, teachers, and others (Clark and Rumbold, 2006). Studies do confirm that children who are taught early to read at home will carry the habit for 
life (Cunningham \& Stanovich, 2001; Strauss, 2009). White (2002) explains that reading is a useful component to be imprinted in the mind of the young, and the art of reading should be carried out throughout their lives. She insisted that parents should not neglect the training of children to read and write. A study conducted by Benevides \& Peterson (2010) revealed that pre-service teachers who were successful had learned reading while young. Their parents had encouraged them to enjoy reading at the library.

Some researchers have argued that when students invest time and enjoy the reading activity, they become competent in mastering the language, (Reyhene, 1998). Others believe that the activity of reading is reflected as a habit when it is purposely focused on a specific goal (Chettri, $\&$ Rout, 2013). Over time, the reader of books understands and appreciates the central themes or purposes for which the books were written and broadened the conceptual understanding of ideas which can be transferred and articulated to form the individual's perception of life (Reyhene, 1998; Chettri \& Rout 2013).

Consequently, developing a reading habit requires daily repetition (Méndez 2018). This repetition helps in mental development as a person learns creativity and critical thinking (Tung \& Chang, 2009). In a specific study (Linzer et al.,1988), 44 medical interns were, given a journal or seminar series to read. The more sessions the interns attended, the more knowledge they gained. Unfortunately, if the students did not have the materials to read or did not live close to libraries that had inadequate reading materials, they were unable to form the reading habit (Ogunrombi, 1995).

\section{Conceptual Framework}

The figure below presents the conceptual framework for the study which investigated the "Reading Habits and their influence on Academic Achievement among students at AIU, Thailand. From the discussion above, it is apparent reading habits have a positive or negative effect on academic achievement. The conceptual framework shows five dependent variables, which define reading habits and their relationship to academic achievement.

1. Reading Attitude. A persons' attitude determines whether the student can develop a reading habit Some students spend most of their time doing video games or watching videos. This type of behavior results in having a poor attitude toward reading (Martinez, Aricak \& Jewell; 2008; Tunde-Awe, 2014).

2. Reading initiative abilities This pertains to whether a student has the self-efficacy to make goals for reading. 
3. Type of materials one reads. Non-academic reading materials include newspapers, novels, etc. Academic reading includes journals and textbooks. Not all reading materials promote academic success.

4. Purpose of reading. Reading for the reader's pleasure, reading for learning and understanding and reading for educational purposes.

5. c) Time spent on reading. Duration of reading to form a reading habit. The person has to spend time reading good books and materials. good books and academic materials.

\begin{tabular}{|c|}
\hline Reading Attitude \\
Reading Frequency \\
Materials read \\
Purpose of reading \\
Time spent on reading \\
\hline
\end{tabular}

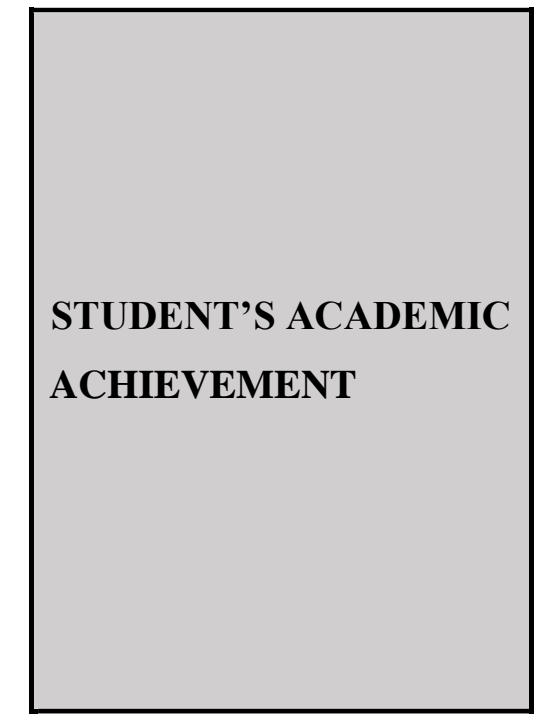

Figure 1. Conceptual Framework on Reading Habits

\section{METHODS}

\section{Research Design}

This study used a quantitative research design that allowed the researcher to find information by gathering numerical data, which was then analyzed and provides accurate and reliable findings. (Leedy 1993; Creswell, 2003). Aliaga and Gunderson (2002) defined quantitative research as an investigation of social phenomena that can be analyzed with the help of mathematically based approaches such as statistics. Using Quantitative research processes enables researchers to collect and analyze data from a large sample of the population in a short period. In addition, it provides descriptive analysis which establishes relationships between variables. This study adopted a quantitative descriptive research design using a survey research method which is considered as one of the most effective ways to gather descriptive data.

\section{Population and Sample}


Participants for this study were undergraduate students at Asia-Pacific International University (AIU), Thailand. A convenience sampling method was used to sample the population. Dörnyei (2007) stated that convenience sampling can be used if the members of the target population meet specific criteria. This sampling method is used because of proximity, availability and willingness to participants. However, Mackey and Gass (2005) points out that bias is the main disadvantage of convenience sampling.

In using the above sampling method, 250 students participated in the study. The sample included students enrolled in various academic disciplines, namely, Business Administration, Arts and Humanities, Religious Studies, Education, English as Second Language (ESL), and Science. These students come from thirty-eight different countries.

\section{Data Collection Instrument}

The survey questionnaire was designed to elicit vital information from the students. Students were to indicate on the 5-point Likert scale their reading attitude, reading frequency, materials read, the purpose of their reading, and time spent on reading. Data collection also included demographic information such as gender, age, nationality, faculty, current academic year, and GPA in that semester.

The questionnaire had five sections. Part A dealt with demographics; Part B had questions on reading attitude, Part $\mathrm{C}$ examined reading frequency, Part $\mathrm{D}$ inquired about materials, Part $\mathrm{E}$ had a list of items on the purpose of reading, Part F students reported about how much time they spent on reading.

Table 1. Variable descriptive statistics and reliability estimates $(\mathbf{n}=\mathbf{2 5 0})$

\begin{tabular}{lccccc}
\hline Variable & M & SD & \#items & skewness & $\begin{array}{c}\text { Cronbach's } \\
\text { Alpha }\end{array}$ \\
\hline Reading attitude & 3.37 & 0.47 & 5 & .18 & .256 \\
Reading frequency & 2.86 & 0.60 & 6 & .12 & .598 \\
Reading materials & 3.16 & 0.60 & 7 & .04 & .696 \\
Reading purposes & 3.90 & 0.59 & 16 & -.63 & .921 \\
Time spent & 2.80 & 0.81 & & .01 & .742 \\
\hline
\end{tabular}

Cronbach's (1951) Alpha was computed to determine the reliability of the instrument. The Cronbach alpha for reading attitude, 5-item scale, was 0.256 and the alpha Cronbach for reading frequency 6 -item scale, was 0.598 , followed by for material read, 7 - item scale, was .696 and purpose of reading 16-point scale, was 921. These scores indicated that the items on the questionnaire were reliable for the actual research. Refer to Table 1. 
The survey questionnaire for this study was adopted from Oriogu and Subair (2017), who had pilot-tested it for validity. Dr. Mantiri, a lecturer at AIU who was an expert in the area of questionnaire validity, checked the instrument for validity, which included correctness and appropriateness of the items on the Likert scale. He concluded that the items were reasonable measures for checking the reading habits of students. A copy of the questionnaire was also sent to the research course advisers for crosschecking and validation.

\section{Procedure for Data Collection}

Permission was given by Asia Pacific International University (AIU) Institution Review Board to collect data. Courtesy visits to the AIU dorms and offices were undertaken to inform the deans and teachers about the study and to introduce the researcher. Students were given the survey when they agreed to participate in the survey and the purpose of the study was explained to them. The researcher collected the completed surveys on the same day. The respondents took approximately 15 minutes to respond to the questions and fill the survey.

\section{Data Analysis}

The data were organized according to research questions and research objectives before analyzing. The particulars were tabulated and analyzed using descriptive statistics, namely; frequency counts, percentages, mean, and standard deviation to describe the information received from the participants. Multiple regression and correlation matrix analysis methods were used to examine how reading affected academic achievement. The statistics were generated using the Statistical Package for Social Sciences (SPSS). The information was later presented using tables for better understanding and analysis. From the analysis of multiple regression, the accepted rule of the hypothesis was $\mathrm{P}<0.05$. The mean interpreted as follows:
$<1.5-$ Strongly Disagree,
1.5-2.4 - Disagree
2.5-3.4 - Neutral
3.5-4.4 - Agree
$1>4.5 \quad-$ Strongly Agree

\section{RESULTS}

The analysis included descriptive statistics such as frequency counts, simple percentage, mean, standard deviation. Other analysis included multiple regression. The results are presented under the following headings: Demography of Respondents, Reading Attitude, Reading Frequency, Materials Read, Purpose of reading, Time spent on reading. 


\section{Demography of Respondents}

Demographic data collected included gender, the age of respondents, nationality, faculty they belong to, and the current academic level in the university.

Table 2. Demographics

\begin{tabular}{llrr}
\hline Variables & & $\mathrm{n}$ & $\%$ \\
\hline Gender & Male & 142 & 56.8 \\
& Female & 108 & 43.2 \\
Age & $17-20$ & & \\
& $21-25$ & 95 & 38.0 \\
& $26-30$ & 121 & 48.4 \\
Faculty & $>30$ & 29 & 11.6 \\
& & 5 & 2.0 \\
& Arts \& Humanities & 53 & 21.2 \\
& Science & 27 & 10.8 \\
& ESL & 9 & 3.6 \\
& Education \& Psychology & 66 & 26.4 \\
& Religious Studies & 27 & 10.8 \\
& Business & 57 & 22.8 \\
& Nursing & 4 & 1.6 \\
& Information Technology & 7 & 2.8 \\
& & & \\
Academic Level & 106 & 42.4 \\
& Freshman & 63 & 25.2 \\
& Sophomore & 50 & 20.0 \\
\hline
\end{tabular}

Table 2 shows the distribution of the respondents by gender, age, faculty, and academic level. It revealed that the majority of the students who participated in study 142 or $56.8 \%$ were male, while 108 or $43.2 \%$ were female.

Respondents distribution by age shows that most of the students $48.4 \%$ who took part in the study were between $21-25$ years and $38.0 \%$ were between $17-20$ years while only $11.6 \%$ were in the range between 26-30 years. This result displays that 2\% of Asia Pacific International University students who took part in the survey are slightly above 30 years.

The distribution of respondents by Faculty reveals that 66 respondents which represent $26.4 \%$ were from the faculty of Education and Psychology accounting for the majority of students who participated in the study. There were 57 respondents from the Faculty of Business, which accounts for $22.8 \%$, and 53 respondents representing 21.2 from the faculty of Arts and Humanities. From the faculty of Religious Studies and Science, there were 27 respondents 
representing $10.8 \%$ for each of these disciplines. The faculty of ESL had only nine respondents, which represent $3.6 \%$ while there were seven respondents from the Faculty of Information and Technology, representing 2.8\%. Finally, there were four respondents from the Faculty of Nursing, representing $1.6 \%$.

Regarding the academic level of respondents, the analysis shows that $42.4 \%$ (106 respondents) were freshmen and $25.2 \%$ (63 students) were sophomore. Respondents from the junior level represent $20.0 \%$ (50 students) and $12.4 \%$ (31 respondents) were senior-level students

\section{Reading Attitude}

Table 3. Reading Attitude

\begin{tabular}{llcccccc}
\hline No & \multicolumn{1}{c}{ Item } & A\% & D\% & N\% & Mean & SD & Decision \\
\hline 1. & $\begin{array}{l}\text { Reading is too time- } \\
\text { consuming }\end{array}$ & 43.2 & 14.8 & 42.0 & 3.36 & 0.89 & $\mathrm{~N}$ \\
2. & Reading is rewarding & 70.8 & 2.8 & 26.4 & 3.88 & 0.78 & $\mathrm{~A}$ \\
3. & Reading is interesting & 66.4 & 10.4 & 23.2 & 3.78 & 0.94 & $\mathrm{~A}$ \\
4. & Reading is boring & 19.6 & 34.4 & 46.0 & 2.79 & 0.94 & $\mathrm{~N}$ \\
5. & Reading is difficult & 30.4 & 28.8 & 40.8 & 3.01 & 1.06 & $\mathrm{~N}$ \\
\hline
\end{tabular}

Respondents agreed that reading is rewarding (Mean=3.88) followed by interesting (Mean=3.78). The rest of the students were neutral, indicating that reading is time-consuming (Mean=3.36), difficult (Mean=3.01) and, boring (Mean=2.79), respectively.

Table 4. Reading Frequency

\begin{tabular}{|c|c|c|c|c|c|c|c|}
\hline No & Item & $\mathrm{A} \%$ & $\mathrm{D} \%$ & N\% & Mean & SD & Decision \\
\hline 1 & $\begin{array}{l}\text { I read a book including print, } \\
\text { audiobooks, and e-books almost } \\
\text { every day }\end{array}$ & 36.4 & 23.2 & 40.4 & 3.16 & 0.985 & $\mathrm{~N}$ \\
\hline 2. & I read once in a couple of days & 67.2 & 22.8 & 36.8 & 3.20 & 0.96 & $\mathrm{~N}$ \\
\hline 3. & I read at least once a week & 51.2 & 19.6 & 29.2 & 3.37 & 1.03 & $\mathrm{~N}$ \\
\hline 4. & I read at least once a month & 39.2 & 34.8 & 26.0 & 3.06 & 1.17 & $\mathrm{~N}$ \\
\hline 5 . & I read less often & 22.0 & 43.2 & 34.8 & 2.68 & 1.10 & $\mathrm{~N}$ \\
\hline 6. & I never read & 79.2 & 6.8 & 14.0 & 1.70 & 1.02 & $\mathrm{~N}$ \\
\hline
\end{tabular}

Findings in Table 4 show the rating of the items on reading frequency. Results explain that almost all participants were neutral stating that they read at least once a week (Mean =3.37), read once in a couple of days (Mean=3.20), read a book including print, audiobooks and ebooks 
everyday (Mean=3.16), read at least once a month $($ Mean=3.06), read less often $(M e a n=2.68)$ and, never read (Mean=1.70), respectively.

Table 5. Materials Read

\begin{tabular}{|c|c|c|c|c|c|c|c|}
\hline No & Item & A\% & D\% & N\% & Mean & SD & Decision \\
\hline 1. & $\begin{array}{l}\text { I read text books most of the } \\
\text { time }\end{array}$ & 39.2 & 19.2 & 41.6 & 3.27 & 0.93 & $\mathrm{~N}$ \\
\hline 2. & $\begin{array}{l}\text { I read newspapers most of } \\
\text { the time }\end{array}$ & 17.6 & 52.4 & 30.0 & 2.53 & 1.05 & $\mathrm{~N}$ \\
\hline 3. & $\begin{array}{l}\text { I read most of the time } \\
\text { magazines }\end{array}$ & 23.2 & 47.6 & 29.2 & 2.64 & 1.08 & $\mathrm{~N}$ \\
\hline 4. & I read novels most of the time & 40.0 & 32.4 & 27.6 & 3.13 & 1.19 & $\mathrm{~N}$ \\
\hline 5. & $\begin{array}{l}\text { I read from websites most of } \\
\text { the time }\end{array}$ & 62.4 & 11.2 & 26.4 & 3.74 & 0.97 & A \\
\hline 6. & I read lecture notes regularly & 38.0 & 14.8 & 47.2 & 3.29 & 0.86 & $\mathrm{~N}$ \\
\hline & I read online articles & 13.2 & 55.6 & 31.2 & 3.50 & 0.94 & A \\
\hline
\end{tabular}

Findings in Table 5 show the rating of the items on Materials Read. The overall participants agreed that they read from websites most of the time (Mean=3.74), followed by online articles (Mean=3.50). For the rest of the other items, students were neutral, indicating that they read lecture notes (Mean=3.29), textbooks (Mean=3.27), and novels (Mean=3.13), respectively. Further, they continued to be neutral, mentioning that they spend their time reading magazines $($ Mean=2.64), newspapers (Mean 2.53).

Table 6. Purpose of Reading

\begin{tabular}{|c|c|c|c|c|c|c|c|}
\hline No & Item & $\mathrm{A} \%$ & $\mathrm{D} \%$ & N\% & Mean & SD & Decision \\
\hline 1. & $\begin{array}{l}\text { Reading helps me to express } \\
\text { my views better. }\end{array}$ & 85.6 & 2.0 & 12.4 & 4.18 & 0.75 & $\mathrm{~A}$ \\
\hline 2. & $\begin{array}{l}\text { Reading helps me to learn new } \\
\text { things }\end{array}$ & 89.6 & 1.2 & 9.2 & 4.34 & 0.73 & A \\
\hline 3. & $\begin{array}{l}\text { Reading helps me for the } \\
\text { imagination of things }\end{array}$ & 79.2 & 2.8 & 18.0 & 4.12 & 0.81 & A \\
\hline 4. & $\begin{array}{l}\text { Reading keeps me from getting } \\
\text { bored }\end{array}$ & 47.2 & 12.8 & 40.0 & 3.47 & 0.98 & A \\
\hline 5. & $\begin{array}{l}\text { Reading enables me to express } \\
\text { myself better }\end{array}$ & 65.6 & 6.4 & 28.0 & 3.81 & 0.88 & A \\
\hline 6. & $\begin{array}{l}\text { Reading helps me to do well in } \\
\text { my studies }\end{array}$ & 81.2 & 2.8 & 16.0 & 4.05 & 0.80 & A \\
\hline 7. & $\begin{array}{l}\text { Reading helps me to create } \\
\text { new ideas }\end{array}$ & 80.4 & 2.0 & 17.6 & 4.09 & 0.77 & A \\
\hline
\end{tabular}




\begin{tabular}{|c|c|c|c|c|c|c|c|}
\hline 8. & $\begin{array}{l}\text { Reading helps me discover } \\
\text { others views }\end{array}$ & 79.2 & 2.4 & 17.6 & 4.06 & 0.76 & A \\
\hline 9. & $\begin{array}{l}\text { Reading helps me to shape my } \\
\text { personality }\end{array}$ & 63.2 & 8.4 & 28.4 & 3.74 & 0.92 & A \\
\hline 10. & $\begin{array}{l}\text { Reading helps me to find about } \\
\text { all the necessary information } \\
\text { about the world }\end{array}$ & 70.8 & 6.0 & 23.2 & 3.91 & 0.88 & A \\
\hline 11. & $\begin{array}{l}\text { Reading helps me to relax } \\
\text { myself }\end{array}$ & 52.0 & 19.2 & 28.4 & 3.45 & 1.04 & $\mathrm{~N}$ \\
\hline 12. & Reading relives my stress & 48.8 & 16.4 & 34.8 & 3.44 & 1.07 & $\mathrm{~N}$ \\
\hline 13. & Reading is fun & 59.6 & 11.6 & 28.8 & 3.61 & 1.00 & A \\
\hline 14. & $\begin{array}{l}\text { Reading makes me gain } \\
\text { knowledge }\end{array}$ & 85.2 & 2.4 & 12.4 & 4.17 & 0.78 & A \\
\hline 15. & $\begin{array}{l}\text { Reading helps me to pass the } \\
\text { examination and quiz }\end{array}$ & 75.2 & 4.0 & 20.8 & 3.95 & 0.82 & A \\
\hline 16. & $\begin{array}{l}\text { Reading helps me to improve } \\
\text { my spoken and written English }\end{array}$ & 76.0 & 1.6 & 22.4 & 4.07 & 0.81 & A \\
\hline
\end{tabular}

Table 6 shows the rating of the items on the purpose of reading as follow: Respondents agreed with almost all the items in regards to the purpose of reading stating that they read to learn new things $($ Mean=4.34), to express views better (Mean=4.18), and to gain knowledge (Mean $=4.17)$.

Followed by reading enhances the imagination of things (Mean $=4.12)$, new ideas, $(\mathrm{Mean}=$ 4.09), spoken and written English (Mean =4.07), discover others views (Mean= 4.06), respectively. Respondents agreed that they could do well in studies because of reading habits (Mean 4.05).

Some respondents agreed that they are keen to read to pass examinations and quizzes (Mean $=3.95)$, to find the necessary information about the world (Mean =3.91), to express themselves better (Mean=3.81), to shape their personality (Mean 3.74), and they read for fun (Mean=3.61). Others agreed that reading keeps them from getting bored (Mean =3.47).

Only for the item 11 and 12 students were neutral, pointing out that reading helps them get relaxed $($ Mean $=3.45)$, and to relieve their stress $($ Mean $=3.44)$.

Table 7. Time Spent on Reading

\begin{tabular}{cccccccc}
\hline No & \multicolumn{1}{c}{ Item } & $\mathrm{A} \%$ & $\mathrm{D} \%$ & $\mathrm{~N} \%$ & Mean & $\mathrm{SD}$ & Decision \\
\hline 1. & I read 30 minutes- 1hour every day & 47.2 & 17.6 & 35.2 & 3.39 & 1.04 & $\mathrm{~N}$ \\
2. & I read 1-2 hours every day & 29.2 & 32.8 & 38.0 & 2.97 & 1.09 & $\mathrm{~N}$ \\
3. & I read 2-3 hours every day & 21.2 & 47.6 & 31.2 & 2.63 & 1.10 & $\mathrm{~N}$ \\
4. & I read 4 hours and above every day & 13.6 & 64.4 & 22.0 & 2.22 & 1.07 & $\mathrm{~N}$ \\
\hline
\end{tabular}


Table 8. Academic Performance of International Students

\begin{tabular}{lcc}
\hline CGPA & Frequency & Percent \\
\hline Below 2 & 12 & 4.8 \\
$2.1-2.5$ & 37 & 14.8 \\
$2.6-3.0$ & 62 & 24.8 \\
$3.1-3.5$ & 93 & 37.2 \\
$3.6-4.0$ & 46 & 18.4 \\
\hline
\end{tabular}

\section{Academic performance of Students.}

The result of the analysis shows that $37.2 \%$ of the 250 students are better achievers. This means their GPA is between 3.1-3.5. Some of the students (24.8\%) are good achievers, and their GPA is between the ranges of 2.6-3.0. The other $18.4 \%$ of the students are high achievers, which means their GPA is between 3.6-4.0. However, $14.8 \%$ of students manage to get a GPA between 2.1-2.5 which is under the category of average students and $4.8 \%$ of students are under the average category because they got below the GPA of 2 .

\section{The Relationship between Reading Habits and Academic Performance}

Table 9. Correlation matrix $(\mathbf{n}=\mathbf{2 5 0})$

\begin{tabular}{llcccccc}
\hline \multirow{2}{*}{ Variable } & \multirow{2}{*}{$\mathrm{M}$} & \multirow{2}{*}{$\mathrm{SD}$} & \multicolumn{4}{c}{ Correlation } \\
\cline { 5 - 8 } & & & 2 & 3 & 4 & \multicolumn{1}{c}{5} \\
\hline 1 & CGPA & 3.50 & 1.10 & .07 & $.19^{* *}$ & $.23^{* *}$ & .07 \\
2 & Frequency & 2.86 & 0.60 & & $.21^{* *}$ & .09 & $.24^{* *}$ \\
3 & Materials & 3.16 & 0.60 & & & $.38^{* *}$ & $.40^{* *}$ \\
4 & Purpose & 3.90 & 0.59 & & & & $.29^{* *}$ \\
5 & Time & 2.80 & 0.81 & & & & - \\
\hline
\end{tabular}

Correlation matrix $(n=250)$ and Multiple regression analyses were conducted to examine the relationship between AIU students reading habits and academic achievement (GPA). Table 10 and 11 summarizes the analysis results.

The reliability estimates for reading attitude (Cronbach's alpha=.256) is unacceptably low and, therefore, not included in the analysis for determining the influence of reading habits on academic performance. Table 10 reports mean, standard deviation, and bivariate correlation among reading habits variables and cumulative grade point averages. Correlation coefficients between reading habits variables and CGPA range from .24 (between frequency and CGPA) to .40 (between materials and CGPA). These are weak, though statistically significant (p. .01). 
Standard multiple regression results are reported in Table 11. The set of reading habits variables explains about $6.5 \%(\mathrm{R} 2=.065)$ of the variance in cumulative grade point averages and is statistically significant $(\mathrm{F}(4,245)=4.34, \mathrm{p}=.002)$. However, the only purpose is a statistically significant predictor $(\mathrm{t}=2.66, \mathrm{p}=.01)$. By itself, purpose explains about $5 \%(\mathrm{r}=.23$, $\mathrm{r} 2=.053)$ of the variance in CGPA.

As can be seen, the purpose of reading is positively and significantly correlated with the criterion, indicating that those who read with the purpose tend to get a higher GPA. Other factors did not contribute to the academic achievement to the multiple regression model.

\section{DISCUSSION}

The results show important findings of the relationship between reading habits and academic achievement. The study reveals that the purpose of reading has a significant relationship with academic achievement. The other factors, namely reading attitude, materials read, reading frequency, and time spent on reading did not contribute to academic performance. Although there are other factors that affect academic achievement, such as students' study ethos, home environment, and parent's level of education, reading habits play a central role in education. Reading prepares individuals to be victorious in all areas of life and every aspect of education and considered as a primary asset for academic performance, and it is an ongoing intellectual process.

Question 1: The purpose of reading was the most significant variable. Most of the respondents strongly agreed that they read to learn new things (Mean=4.34), to express views better (Mean=4.18), to gain knowledge (Mean =4.17). Others read for the imagination of things (Mean $=4.12)$, new ideas. $($ Mean= 4.09), spoken and written English $($ Mean $=4.07)$, discover others views (Mean=4.06), to do well in their studies (Mean 4.05), respectively. The analysis also indicates that students have tendencies to read lecture notes and textbooks to pass the examinations as this is the most important reason for reading.

Students agreed that they read to pass examinations and quizzes (Mean $=3.95$ ), to find the necessary information about the world (Mean =3.91), to express themselves better (Mean=3.81), to shape their personality (Mean 3.74), and reading as fun (Mean=3.61) and from getting bored (Mean =3.47).

Findings from this study confirm the result of two studies which found that pupils are interested in reading to pass quizzes and examinations (Akabuike \& Asika, 2012;). Another study by 
Owusu-Acheaw (2014) showed that students purposely read in order to improve their selfexpression.

The results also showed that the majority of the students agreed that reading is rewarding (Mean=3.88) and interesting (Mean=3.78). This study confirms the findings from Clark and Rumbold (2006) which indicated that who students who read for pleasure are rewarded with intelligence. In addition, Lukhele (2013) revealed that students who consider reading as a pleasant activity had excellent English proficiency, These results, however, contradict Akabuike, \& Asika, ( 2012) who found that Azikiwe University Awaka and Anambra State University students in Ethiopia had negative attitude towards reading at Nnamdi.

Regarding the types of materials read most of the respondents agreed that they read online articles (Mean=3.74), from websites (Mean=3.50), while others were neutral stating that they read lecture notes(Mean=3.29), and textbooks (Mean=3.27), novels (Mean=3.13), respectively. The results of this study match the results of the research conducted by Owusu-Acheaw and Larson (2014) where students in Ghana specified that they read lecture notes, textbooks, and novels. Some of AIU students stated that they spend their time reading magazines (Mean=2.64), newspapers (Mean 2.53). In fact the students are interested in reading digital materials than printed materials. These findings confirm Ogbodo (2010) findings, which emphasized that reading magazines and fictitious materials are more interesting to students than reading textbooks and professors notes.

Some students indicated that reading helps them to relax (Mean $=3.45$ ), and it helps them relieve stress (Mean =3.44). The findings of this recent study resemble the results of OwusuAcheaw and Larson (2014), who indicated that students read when they are bored.

In terms of reading, frequency, and time spent on reading this study indicated most of the students were neutral.

Question 2: Regarding the level of academic achievement, the study shows that $18.4 \%$ of the AIU student population were high achievers, and $37.2 \%$ were medium to high achievers, while $24.8 \%$ were medium achievers. However, $14.8 \%$ of students come under the category of average, and $4.8 \%$ were in the below-average category. Students who love to read with a purpose acquired a high GPA than the other students who didn't pay much attention to reading. This conclusion agrees with that of Benevides \& Peterson (2010). who identified the impact of reading habits on learner's academic output. 
With regards to the effect of reading habits on academic achievement, the correlation values indicate the purpose of reading. Thus, students reading habits that are correlated to the purpose of reading are likely to have better academic performance and a higher CGPA.

Question 3: An analysis of data on frequency of reading materials, the purpose of reading and time spent for reading, revealed that materials read, and purpose of reading showed a relatively higher correlation with CGPA achievement. The purpose of reading was most significant in affecting the academic success of a large number of students.

Similarly, according to the regression analysis of the same variables, the purpose of reading showed a comparatively higher level of significance in CGPA achievement ( $p$.01) by AIU students. At the same time, materials read also showed relatively higher significance in the 232 potential impacts that it might have on achieving higher CGPA.

In summary, the study showed that material read and the purpose of reading have a higher effect in achieving better academic results in AIU. Therefore, the adjusted R2 (R2=.065, $\mathrm{F}(4,245)=4.34, \mathrm{p}=.002)$ can be a mathematical expression of the means for the AIU students to earn better academic result $(\mathrm{p}=0.002)$.

\section{Conclusion}

This study was conducted to ascertain the influence of reading habits on the academic achievement of International students at Asia-Pacific International University, Thailand. The study findings show that students have cultivated some type of reading habit for they read online articles from the website. Students read to improve their academic outcomes and to reduce stress. Reading was also found to influence their knowledge acquisition, world views, and skill in speaking and writing English. However, the lack of interest in reading is a major problem It is, therefore, crucial for educators to emphasize the importance of reading.

To sum, there was a strong positive correlation between the purpose of reading and academic achievement. This study seems to indicate that the majority of the students who took part in the study have a positive reading attitude but have lower reading habits.

\section{Recommendations}

A salient recommendation from the findings is for policymakers to develop plans for increasing students' reading habits. This includes ensuring the availability of reading resources in the libraries and resource rooms. In addition, professors in the university should develop strategies for motivating students to develop interests in reading.

Further research should be conducted in other universities on best practices for encouraging college students' reading habits that would affect their academic achievement. In addition, 
future research should use other research designs and data collection methods to have in-depth understanding of the development of reading habits 


\section{REFERENCES}

Adams, A. (1996). Even basic needs of young are not met. Retrieved from http://tc.education. pitt.edu/library/SelfEsteem

Aden, A. A; Yahye, Z. A., Dahir, A. M. (2013). The effect of student's attendance on academic performance: A Case study at Simad University Mogadishu. Educational and Management Sciences SAVAP International, 4(6).

Adunola, O. (2011). The impact of teachers' teaching methods on the academic performance of primary school pupils in Ijebu-Ode Local Cut Area of Ogun State. Ogun State, Nigeria: Ego Booster Books.

Akabuike, I., G., \& Asika, I. E. (2012). Reading habits of undergraduates and their academic performances: Issues and perspectives. An International Multidisciplinary Journal, Ethiopia, 6(2), 246-257. DOI://dx.doi.org/10.4314/afrrev.v6i2.22.

Aliaga, M., \& Gunderson, B. (2002). Interactive statistics. Thousand Oaks: Sage Publications.

Alghail, A. A. A., \& Mahfoodh, O. H. A. (2016). Academic reading difficulties encountered by international graduate students in a Malaysian university. Issues in Educational Research, 26(3), 369-386.

Allahi, B. Y., \& Khandai, H. (2015). Academic achievement and study habits of college students of District Pulwama. Journal of Education and Practice, 6(31). Online. Retrieved from https://files.eric.ed.gov/fulltext/EJ1083409.pdf

Ameyaw, S., \& Anto, S. K. (2017). Gender variation in reading habits in schools in Moland: A case study of Asantekwaa S.D.A. Junior High School. European Journal of Education Studies, 3(5), 688,704. doi: 10.5281/zenodo.573273

Ameyaw, S. , \& Anto, S. K. (2018) Read or perish: Reading habits among students and its effect on academic performance: A Case study of Eastbank Senior High School Accra. Library Philosophy and Practice. (e-journal). 1748https://digitalcommons.unl.edu/libphilprac/1748

Andayani, U., \& Maryam, S. (2018). The portrait of reading habit and interest of Tangerang City community. A Paper presented at the Proceedings of the 2nd International Conference on Culture and Language in Southeast Asia (ICCLAS 2018), https://doi.org/10.2991/icclas-18.2019.56.

Anderson, R. C., Wilson, P.T., \& Fielding, L. G. (1988). Growth in reading and how children spend their time outside of school. Reading Research Quarterly, 23, 285-303.

Annamalai, S., \& Muniandy. B. (2013). Reading habit and attitude among Malaysian polytechnic students. International Online Journal of Educational Sciences, 5(1), 3241. 
Applegate, A. J. et al. (2014). The Peter effect revisited: Reading habits and attitudes of college students. Literacy Research and Instruction,53(3),188-204. DOI: 10.1080/19388071.2014.898719

Asagwara, C. G. (2000). Study habits dimensions and effective application in schools. Calabar, Nigeria: Sea Fruit Company.

Asian Correspondent. (2012). Why do Thais read so few books each year? Retrieved from https://asiancorrespondent.com/2012/08/why-do-thais-read-so-few-books-eachyear/

Bahruddin, M. F., Wan Hasnol. W. M. F., Ramsi, M. F. M, \& Kadir, M. R. A. (2015). Understanding of reading habits among students in Malaysia: A Review. A Conference Paper- International Business Information Management Association Conference (IBIMA) in Armstead, Netherland.

Bashir, I., \& Mattoo, N. H. (2012). A Study on habits and academic Among adolescents (1419) years. International Journal of Social Science Tomorrow. 1(5). 1-5.

Benevides, T., \& Peterson, S. S. (2010). Literacy attitudes, habits and achievements of future teachers. Journal of Education for Teaching, 36(3),291-302. DOI:10.1080/02607476.2010.497375

Bignold, H. (2003). Gender difference and reading. Journal of School Librarian, 50(3), 122133.

Bond, G. L., Tinker, M. A., Wasson, B. B., \& Wasson, J. B. (1994). Reading difficulties: Their diagnosis and correction (7th Ed.) London, UK: Pearson.

Books Aid International. (2003). Is reading a dying pastime? Readers across in globe say no! Retrieved on November 8, 2006, Retrieved from ttp://www.bookaid.org/cms.cgi/site/news/

Blazar, D. (2015). Effective teaching in elementary mathematics: Identifying classroom practices that support student achievement. Economics of Education Review, 48, 1629.http://nrs.harvard.edu/urn-3:HUL.InstRepos:27112692

Briggs, L. D. (1987). A poor attitude: A deterrent to reading improvement. Reading Horizons, 27(3), 202-208.

Bulgurcuoglu, A. N. (2016). Relationship between critical thinking levels and attitudes towards reading habits among pre-service physical education teachers. Educational Research and Reviews, 11(8)., 708-712.

Capps, M., \& Huang, S. H. (2015). Reading habits of education majors. Literacy Information and Computer Education Journal, 6(3). 1976-1982. 
Chen, J. J., Yang, S. C. (2014). Promoting cross-cultural understanding and language use in research-oriented internet mediated intercultural exchange. Computer Assisted Language Learning, 29(2), 262-288. https://doi.org/10.1080/09588221.2014.937441

Chettri, K., \& Rout S. K. (2013). Reading habits - An overview. IOSR Journal of Humanities and Social Science (IOSR-JHSS), 14(6),13-17. Retrieved from www.Iosrjournals.Org

Choomthong, D. (2014). Preparing Thai students' English for the ASEAN Economic Community: Some pedagogical implications and trends. Language Education and Acquisition Research Network (LEARN) Journal, 7(1), 45-57.

Clark, C. \& Rumbold, K. (2006). Reading for pleasure: a Research Overview. London: National Literacy Trust.

Collins, A., Brown, J. S., \& Newman, S. E. (1989). Cognitive apprenticeship: Teaching the crafts of reading, writing, and mathematics. In L. B. Resnick (Ed.), Knowing, Learning, and Instruction: Essays in Honor of Robert Galser. Hillsdale, NJ: Erlbaum.

Creswell, J. W. (2003). Research design: Qualitative, quantitative \& mixed method approaches. ( 2 ed.). Thousand Oaks, CA: Sage Publications, Inc.,

Cronbach, L. J. (1951). Coefficient alpha and the internal structure of tests. Psychometrika, 16(3), 297-334.

Crow, L, D., \& Crow. A. (1969). Adolescent development and adjustment, New York: Mc Graw-Hill Book Company.

Cunningham, A. E. \& Stanovich, K. E. (1998). What reading does for the mind? American educator. 22(1): 8-15.

Cunningham, A. E, \& Stanovich, K. E. (2001). What reading does to the mind. Journal of Instruction, 1(2), 137-149.

Dornyei, Z. (2007). Research methods in applied linguistics. Oxford: Oxford University Press.

Fatiloro, O. F., Oyekola, A. A., \& Hameed, B. A. (2017). A survey on the reading habits among colleges of education students in the information age. Journal of Education and Practice, 8(8), 106-110. ISSN 2222-288X (Online).

Ganyaupfu, E. M. (2013). Factors influencing academic achievement in quantitative courses among Business students of Private Higher Education Institutions. Journal of Education and Practice, 4(15), 57-65.

Gunasekara, P. W. (2002). Education in Sri Lanka. An Overview. Colombo, Sri Lanka: Deepani Printers.

Hansen, J. B. (2000). Student performance and student growth as measure of success: A evaluator's perspective. A Paper presented at annual meeting of the American Educational Research Association New Orleans, Louisiana, 
Heath, S. H. (2014). A spotlight on preschool: The influence of family factors on children's early literacy skills.

Hocking, C. (2008), The contributing factors to student absenteeism/truancy and the effectiveness of social services and interventions. Social Work Student Papers. Paper18. Retrieved from http:// digitalcommons.providence.edu/cgi/viewcontent.cgi

Horbec, D. (2012). The link between reading and academic success. English in Australia, 47(2), 58-6. Retrieved from https://www.goodreads.com/quotes/625708-today-areader-tomorrow-a-leader-margaret-fuller

Huang, S., Capps, M., Blacklock, J., \& Garza, M. (2014). Reading habits of college students in the United States. Reading Psychology, 35, 437-467.

Ismail, N., \& Elias, S. (2009). An Analysis of the reading attitudes and habits among ESL Part One Diploma students in MARA, University of Technology Malaysia, Johor Branch. The International Journal of Interdisciplinary Social Sciences, 4(8), 181-190.

Kidd, D. C., \& Castano, E. (2013). Reading literary fiction improves theory of mind. Science, 342, 377-380. doi:10.1126/science .1239918

Krashen, S. (2009). 88 generalizations about free voluntary reading. Retrieved from http://www.sdkrashen.com/index.php

Krashen, S., \& Williams, C. (2012). Is self-selected pleasure reading the cure for the long-term ELL syndrome? A Case history NABE Perspectives. Retrieved from

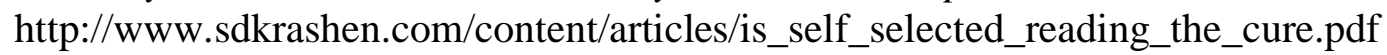

Krashen, S. (2004). The power of reading. Portsmouth, NH: Heinemann and Westport: Libraries Unlimited.

Krashen, S. (1996). Under attack: The case against bilingual education. Culver City, CA: Language Education Associates.

Leedy, P. (1993). Practical Research: Planning and Design (5th ed.). Macmillan Publishing Company, New York.

Levine, L. E., Waite, B. M., \& Bowman, L L. (2007). Electronic media use, reading and academic distractibility in college youth. CyberPsychology \& Behavior, 10(14), 560566. DOI: $10.1089 / \mathrm{cpb} .2007 .9990$.

Linzer, M., Grown, J. T., Frazier, L. M.; \& DeLong, E. R. (1988). Impact of a medical journal club on house-staff reading habits, knowledge and critical appraisal skills: A randomized control tiral. JAMA Network Open, 260(17), 2472-2608.

Liu, Z. (2000). Reading is on the rise in China. Retrieved March 3, 2006, from http://www.honco.net/100day/02/2000-0526-liu.html 
Lukhele, B.B.S. (2013). 'Exploring relationships between reading attitudes, reading ability and academic performance amongst primary teacher trainees in Swaziland'. Reading \& Writing, 4(1), 28-35 http://dx.doi.org/10.4102/rw.v4i1.28

Mackey, A., \& Gass, S. M. (2005). Second language research: Methodology and design. Mahwah, NJ, US: Lawrence Erlbaum Associates Publishers.

Mahfoodh, O. H. A. (2014). Oral academic discourse socialisation: Challenges faced by international undergraduate students in a Malaysian public university. International Education Studies, 7(2), 10-17. http://dx.doi.org/10.5539/ies.v7n2p10

Martinez, R. S., Aricak, O. T., \& Jewell, J. (2008). Influence of reading attitude on reading achievement: A test of temporal interaction model. Psychology in the Schools, 45(10), 1010-1023. https://doi.org/10.1002/pits.20348

Méndez. M. (2018) Ten simple rules for developing good reading habits during graduate school and beyond. PLOS Computational Biology, 14(10): e1006467. https://doi.org/10.1371/journal.pcbi.1006467

Muhdin M. H. (2016). Determinants of Economics students' academic performance: A case study of Jimma University, Ethiopia. International Journal of Scientific and Research Publications, 6(1), 566-571.

Mushtaq, I., \& Khan, S. N. (2012). Factors Affecting Students' Academic Performance. Global Journal of Management and Business Research, 12 (9), 16-22.

Naderi, H. Abdullah, R., Tengku-Aizan, H., Sharir, J. \& Kumar, V. (2009). Intelligence, creativity and gender as predictors of achievement among undergraduate students. Journal of American Science, 5(3), 8-19.

National Statistical Office of Thailand. (2008), Initial summary of a survey of the Thai population's reading behaviour, Retrieved 20 December 2010, National Statistical Office of Thailand database.

Ngamwittayaphong, A. (2011) Factors affecting the promotion of a reading culture in Thailand. Retrieved from https://www.tkpark.or.th/stocks/extra/00052d.pdf

Obaidullah, M., \& Rahman. (2018). The impact of internet and social media on the habit of reading books: A case study in the Southern Region of Bangladesh. Studies in English Language and Education, 3(1), 25-39

OECD. (2014). PISA 2012 results in focus: What 15-year-olds know and what they can do with what know. Rey from http://www.oecd.org/pisa/keyfindings/pisa2012-results-overview.pdf

Ogbodo, R. O. (2010). Effective Study Habits in Educational Sector: Counselling Implications. $\begin{array}{lllll}\text { Edo Journal of Counselling 229-239. } & \text {, }\end{array}$ https://www.ajol.info/index.php/ejc/article/view/63610 
Ogunrombi, S. A. (1915). Factors affecting the reading habits of secondary students. Library Review, 44(4), 50-57

Okwilagwe, O. A. (1998). A New Approach to Reading Comprehension and Summary for schools and colleges. Ibadan, Nigeria: Sterling - Horden Publishes (Nig) Ltd.

Oriogu C. D., Subair, R. E., Oriogu-Ogbuiyi, D. C., \& Ogbuiyi, S. U.(2017). Effect of reading habits on the academic performance of students: A case study of the students of Afe Babalola University, Ado-Ekiti, Ekiti State. Teacher Education and Curriculum Studies. 2(5), 74-80. Doi: 10.11648/j.tecs.20170205.13.

Owusu-Acheaw, M., \& Larson, A. G (2014) Reading habits among students and its effect on academic performance: A study of students of Koforidua Polytechnic. Library Philosophy and Practice (e-journal). Retrieved on 10th April 2017fromhttp://digitalcommons.unl.edu/libphilprac/1130

Palani, K. K. (2012). Promising reading habits and creating literate social. International Reference Research Journal, 3(1), 91-94.

Poedjiastutie, D. (2018). Indonesian school students reading habits: A sociocultural perspectives. International Journal of English Language and Literature Studies, Asian Economic and Social Society, 7(4), 94-100.

Reyhene, K. (1998). Persistence of reading disabilities. American Educational Research, 28(4), 875-882.

Sangkaeo, S. (1999). Reading habit promotion in Asian libraries. Paper presented at 65th IFLA Council and General Council and General Conference, Bangkok, Thailand.

Singer, L. M., \& Alexander, P.A. (2017).Reading across mediums: Effects of reading digital and print texts on comprehension and calibration. The Journal of Experimental Education 85, 155-172. https://doi.org/10.1080/00220973.2016.1143794

Smithikrai, C., Homklin, T., Pusapanich, P., Wongpinpech, V., \& Kreausukon, P. (2018). Factors influencing Students' Academic Success: The Mediating Role of Study Engagement. The Journal of Behavioral Science, 13(1), 1-14. Retrieved from https://www.tci-thaijo.org/index.php/IJBS/article/view/100674

Snow, C. E., Burns, L. S., \& Griffin, P. (1998). Preventing reading difficulties in young children. Washington, D.C: National Academy Press.

Strauss, M. J. (2009) Reading habits and attitudes of Thai L2 students. University of South Africa, Pretoria, http://hdl.handle.net/10500/2276

Tor-Akwer, H. F., \& Chour, M. T. (2014). The influence of demographic factors on reading comprehension amongst undergraduate students at Benue State University Makurdi. IOSR Journal of Research \& Method in Education, 4(6), 6-11. 
Tunde-Awe, N. B. (2014) Relationship between reading attitudes and reading comprehension performance of secondary students in Kwara State, Nigeria. Review of Arts and Humanities, 3(2)203-215. ISSN: 2334-2927.

Tung, C-A. \& Chang, S-Y. (2009). Developing critical thinking through literature reading. Feng Chia Journal of Humanities and Social Sciences, 19, 287-317.

Tynjälä, P. \& Välimaa, J., \& Sarja, A. (2003). Pedagogical perspectives on the relationships between higher education and working life. Higher Education. 46, 147-166. 10.1023/A:1024761820500.

Wagner, S. (2002). The reading habits of teams. Journal of Reading Today, 46, 3-4.

Walters, B. Y., \& Soyibo, K. (2001). An Analysis of high school students' performance on five integrated science process skills. Research in Science \& Technological Education, 19. 133-145. 10.1080/02635140120087687.

White, Ellen G. (2002). Child guidance. Hagerstown, MA: Review and Herald Publishing House.

Whitten, C., Labby, S., \& Sullivan, S. (2016). The impact of pleasure reading on academic success. Journal of Multidisciplinary Graduate Research, 2(4) 48-4.

Yamoah, E. (2015). An investigation into the reading habits of students in Ayeduase. (Unpublished dissertation). Kwame Nkrumah University of Science and Technology, Ghana. 